\title{
An Alternative Foreign Indebtment Model for the State Economic Enterprises Which Construct the Nuclear Power Stations Özcan ERDOĞAN*
}

\author{
Dumlupınar University, Turkey \\ akbars_16@mynet.com \\ ${ }^{*}$ Corresponding author
}

\begin{abstract}
Keywords: Foreign Indebtment, State Economic Enterprises, Nuclear Power Station, Consumer Price Index, Treasury Bail, International Stock Market, Dividend.
\end{abstract}

\begin{abstract}
Foreign indebtment for the state economic enterprises is the project credit. To provide this loan is given the additional guaranties for the creditor. Constructing the nuclear power station is an long-term investment and financing of this investment will be done by the long-term foreign indebtment. In financing of the investment must been considered also the quinquennial period of trial production. The interest calculation of this investment must be done over the national consumer price index. In the quinquennial period of trial production must be done the dividend payment for the creditors. This loan must be done by the treasury bail. These bonds must processed in the international stock markets.
\end{abstract}

\section{Introduction}

Thermal power generation is a style of economical energy production by the nuclear power stations. This production style destroys the nature at least not in the way according to the other ways of power generation. Thermal power generation by the nuclear power stations is the qualified way of power generation. The power generation in this way presses for the qualified personels. Power generation by the nuclear power stations prepares the infrastructure for the scientific researchs at many main science branches. Constructing the nuclear power stations causes to the developments at many branches of the industry[1]

To construct the nuclear power stations without being the alternative of borrowing is impossible. Construction of the nuclear power stations are generally made real by the state economic enterprises. The technical specifications at construction of the nuclear power plants entail for being constructed by the state economic enterprises at the construction work of power plants. The technology transfer at construction of the power plants is done to the countries which get the construction done by the state economic enterprises.[2]

The nuclear power stations are one of the most rooted solutions to need of the energy on our century.

\section{State Economic Enterprises Will Construct the Nuclear Power Stations}

The state economic enterprises which will construct the nuclear power stations, need for the charter capital and the operational capital. The $R \& D$ (research and development) expenditures are included to the operational capital but, the $R \& D$ expenditures form the fixed capital after $R \& D$ studies have resulted. The charter capital and the operational capital must constitute to approximately 50 percent of the total capital of the nuclear power station. The charter capital and the operational capital are meet by the state. The rest of total capital must be procured by the way of indebtment from the national or international capital markets[3].

The need of fixed capital of the nuclear power plants changes to the reactor number. The reactors are the brains and the main production devices of nuclear stations. Production and design of the reactors are made by the phenomenal firms in the world and the firms belong to the developed countries. Nowadays, cost of the design and the production of a reactor are approximately 5 billion 
dollars. In addition, the countries could want preferably to have the enrichment institutions of nuclear fuel. The enrichment institutions are cheap according to the reactors. The main production devices of enrichment institutions are the centrifugals[4].

The capital adequacy of these state economic enterprises must be proper to the international rules. Also the capital productivity and the capital profitableness of this companies must be same with the other international state economic enterprises which construct the nuclear power stations. Later the nuclear stations according to the first nuclear stations will have more advanced technology for the same country but, later the nuclear stations according to the first nuclear stations will be more profitable and productive[5].

The basic safety rules are more important from the profitableness in constructing for the nuclear power plants. Since effects of the nuclear accidents couldn't been remove for years. The main condition is the conditious education and the applied training for safety in construction and operation for the plants. The new generation of nuclear reactors is planned to operate with the low radioactive elements such as thorium and the new reactors will decrease the safety costs according to the conventional reactors[6].

Establishing conditions for the state economic enterprises in constructing for the nuclear reactors will change all over the world.

\section{Characteristics of Bonds Which Will Finance the Construction of the Nuclear Reactors}

In the first place, the indebtment bonds for constructing the nuclear reactors will be dated for 15 years. That is to say, this indebtment is long dated. Construction stage of the nuclear reactors only take 10 years. Trial production of the nuclear reactors continues for 5 years. That is, indebtment for the nuclear reactors is a project credit. This project credit will be provided by the capital market and this indebtment will be a foreign indebtment[7].

In the model that It has suggested, being corroded the principal of bond by inflation will be avoided as paying the interest according to the annual CPI(Consumer Price Index) for the first 10 years. This model of indebtment is sufficient for the countries which apply the system of floating rate of exchange and it encourages the indebtment. The same model hinders for being corroded the principal of bond by inflation for the countries which apply the fixed exchange rate system but, the debtor countries must attach the inflationist abrasion amount to the principal in subsequent years at rate of the CPI in the fixed exchange rate system[8].

The annual yield formula of bond is as follows in the system of floating rate of exchange. In the formula, $\mathrm{AY}_{\mathrm{FRE}}$ symbolises the annual yield of bond in the system of floating rate of exchange; $\mathrm{CPI}_{\mathrm{i}}$ symbolises the annual consumer price index and $\mathrm{P}$ symbolises the principal.

$$
A Y_{F R E}=\sum_{i=1}^{10} C P I_{i} \% x P
$$

The annual yield formula of bond is as follows in the system of fixed exchange rate. In the formula, $\mathrm{AY}_{\mathrm{FER}}$ symbolises the annual yield of bond in the system of fixed exchange rate.

$$
\mathrm{AY}_{\mathrm{FER}}=\left[\sum_{\mathrm{I}=1}^{10}\left(\mathrm{CPI}_{1} \% \mathrm{xP}\right)+\mathrm{P}\right]-\sum_{\mathrm{i}=1}^{10}\left(\mathrm{CPI}_{1} \% \mathrm{xP}\right)
$$

In the second year, the annual yield formula of bond is as follows in the system of fixed exchange rate. I must say to continue the CPI addings for the next years.

$$
\mathrm{AY}_{\mathrm{FER}}=\left\{\sum_{\mathrm{i}=2}^{10}\left(\mathrm{CPI}_{2} \% \mathrm{x}\left[\sum_{\mathrm{i}=1}^{10}\left(\mathrm{CPI}_{1} \% \mathrm{xP}\right)+\mathrm{P}\right]\right\}-\sum_{\mathrm{i}=2}^{10}\left(\mathrm{CPI}_{2} \% \mathrm{xP}\right)\right.
$$

The annual yield formula of bond is as follows in the system of floating rate of exchange when 5 percent of profit of the reactor is distributed as the annual dividend in the period of trial production. In the formula, D symbolises the annual dividend which scatters earnings per bond.

$$
\mathrm{AY}_{\mathrm{FRE}}=\sum_{\mathrm{i}=11}^{15} \mathrm{CPI}_{\mathrm{i}} \% \mathrm{XP}+\mathrm{D}
$$


The annual yield formula of bond is as follows in the system of fixed exchange rate when 5 percent of profit of the reactor is distributed as the annual dividend in the period of trial production.

$$
\mathrm{AY}_{\mathrm{FER}}=\left[\sum_{\mathrm{I}=11}^{15}\left(\mathrm{CPI}_{1} \% \mathrm{xP}\right)+\mathrm{P}\right]-\sum_{\mathrm{i}=11}^{15}\left(\mathrm{CPI}_{1} \% \mathrm{xP}\right)+\mathrm{D}
$$

In the twelfth year, the annual yield formula of bond is as follows in the system of fixed exchange rate when 5 percent of profit of the reactor is distributed as the annual dividend in the period of trial production. It isn't necessarily to say to continue the CPI addings for the next years.

$$
A Y_{F E R}=\left\{\sum_{i=11}^{15}\left(C P I_{11} \% x\left[\sum_{i=11}^{15}\left(C P I_{11} \% x P\right)+P\right]\right\}-\sum_{i=12}^{15}\left(C P I_{12} \% x P\right)+D\right.
$$

The reactor management could liquidate within the framework of a payment plan the complete of debts when the period of trial production ended. This indebtment offer is especially for the developing countries. The project indebtments consiquently contribute positive for the balance of payments. This indebtments must done under bail of the treasury in the international stock markets.

\section{Encouragements Which Will Be Provided for the Creditors in Indebtments for the Nuclear Reactors}

Some encouragements must be given for the creditors to ease the indebtment for the nuclear reactors. The encouragements ease to loan for the investors to the firm which will construct the nuclear reactors. Encouragements for the nuclear reactors decrease risks of the investment at the same time but, the encouragements increase the social cost of investments. It is need to contrast the economic benefits of investments with the social cost of encouragements and the encouragement decision must decide according to the result of this comparison[9].

The most important encouragement for the earnings of bonds is the tax allowance. Tax allowance decreases the risk of receivable for the creditor. Tax allowance helps to form the proper investment setting for indebtment. Tax allowance helps to form the capital centralization for the debtor country. Tax allowance provides the capital productivity for the debtor firms[10].

The other encouragements for the debtors of bonds are the birthright for purchasing over a certain limit of bonds and the investment subsidy for purchasing over a certain limit of bonds. The birthright is a encouragement in the switch important for the investors, for especially the creditors of bonds since the investors and the creditors will feel over confidence themselves by birthright. The investment subsidy provides that the creditors transfers to the debtor country their capitals[11].

The investment incentives help to form the capital centralization in debtor country. In addition, the investment incentives are necessary being planned at the sectoral base.

\section{Conclusions}

The nuclear technology is necessary being transferred to the developing country even if also by indebtment. The society of debtor country must put up with the social cost and the economic cost since the nuclear technology contributes to the social welfare. I have meant thing here that it is to produce the energy by the nuclear technology. Otherwise I don't defend to acquire the nuclear technology by the military objectives either. In addition, the nuclear technology is used by the scientific objectives and the nuclear technology for the medical searchs is a good example for this.

Indebtment for acquiring the technology of nuclear energy production could be in the high cost but, the nuclear technology provides to develop in the other main sciences for the debtor country. The nuclear technology necessitates to provide the quality in the technical education and the quality in technical education means increase in the total production. The increase in total production brings the result of increase in tax incomes. The increase in tax incomes leads to the want of the equity of taxation in the society. As a result, the equity of taxation brings about the social welfare. 


\section{References}

[1] Ryoichi Komiyama and Yasumasa Fujii, Modeling Analysis of Electric Vehicle Penetration Scenario using Dynamic Optimal Power Generation Mix Model with High Temporal Resolution, Electrical Engineering in Japan, Vol.: 199, Iss.: 3(May 2017), pp. 4, 6, 8 and 10-11.

[2] Greg J. Duncan, Years of Poverty, Years of Plenty, Research Reports, The Wilson Quarterly(1976-), Vol.: 8, No.: 3(Summer 1984), pp. 44 and 46.

[3] Jerry Ross and Barry M. Staw, Organizational Escalation and Exit: Lessons from the Shoreham Nuclear Power Plant, Academy of Management Journal, Vol.: 36, No.: 4(1993), pp. 702, 704, 706 and 708, 711-712.

[4] R. Naslain, Design, Preparation and Properties of Non-Oxide CMCs for Application in Engines and Nuclear Reactors: An Overview, Composites Science and Technology, Vol.: 64, Iss.: 2(February 2004), pp. 156, 158, 160 and 163-165.

[5] Michael G. Pollitt, Ownership and Efficiency in Nuclear Power Production, Oxford Economic Papers, Vol.: 48, Iss.: 2(April 1996), pp. 343, 345, 347, 349 and 351-353.

[6] H. Müller and G. Pröhl, ECOSYS-87: A Dynamic Model for Assessing Radiological Consequences of Nuclear Accidents, Health Physics, Vol.: 64, Iss.: 3(March 1993), pp. 232, 234, 236, 238, 241-243.

[7] Yangbo Du and John E. Parsons, Update on the Cost of Nuclear Power, Analysis Report, A Joint Center of the Department of Economics, MIT Energy Initiative and Sloan School of Management, May 2009, pp. 3, 5, 7, 9, 11, 13-15.

[8] Ann Dougherty and Robert Van Order, Inflation, Housing Costs, and the Consumer Price Index, The American Economic Review, Vol.: 72, No.: 1(Mar., 1982), pp. 155, 157, 159, 161-163.

[9] Martin B. Zimmerman, Learning Effects and the Commercialization of New Energy Technologies: The Case of Nuclear Power, The Bell Journal of Economics, Vol.: 13, No.: 2(Autumn, 1982), pp. 298, 300, 302, 304, 307-308.

[10]Gerard M. Brannon and Elliott R. Morss, The Tax Allowance for Dependents: Deductions versus Credits, National Tax Journal, Vol.: 26, No.: 4(December 1973), pp. 600, 602, 604, 606 and 608-609.

[11]Gilles Saint-Paul, Fiscal Policy in an Endogenous Growth Model, Quarterly Journal of Economics, Vol.: 107, Iss.: 4(November 1992), pp. 1244, 1246, 1248, 1250 and 1252-1255. 